Volume 10, Nomor 1, Mei 2018, pp 41-52 Copyright (C) 2017 Jurnal Akuntansi Maranatha, Program Studi Akuntansi, Fakultas Ekonomi, Universitas Kristen Maranatha. ISSN 2085-8698 | e-ISSN 2598-4977. http://journal.maranatha.edu

\title{
Analisis Faktor-Faktor yang Mempengaruhi Penilaian KinerjaSatuan Kerja Perangkat Daerah Di Kota Bandung
}

\author{
Yuliana Gunawan \\ Fakultas Ekonomi Program Studi Akuntansi-Univ.Kristen Maranatha \\ (Jl. Prof. Drg. Suria Sumantri No. 65, Bandung) \\ yuliana_ok99@yahoo.com \\ Aurora Angela \\ Fakultas Ekonomi Program Studi Akuntansi-Univ.Kristen Maranatha \\ (Jl. Prof. Drg. Suria Sumantri No. 65, Bandung) \\ aurora.ang31@yahoo.com \\ Ilham Pranata \\ Fakultas Ekonomi Program Studi Akuntansi-Univ.Kristen Maranatha \\ (Jl. Prof. Drg. Suria Sumantri No. 65, Bandung) \\ ilhampranata11grt@gmail.com
}

\begin{abstract}
The purpose of this research is to reveal other factors that may affect the performance of SKPD in Indonesia. Factors used are incentive-oriented performance appraisal system, exploration-oriented performance appraisal system with contractibility as a moderating variable. This research was done in 3 SKPD located in Bandung City. Moderated Regression Analysis (MRA) have been used to analyzed the hypothesis. The results showed that incentive-oriented performance appraisal system and exploration-oriented performance appraisal system had no effect on SKPD performance, and when moderated by contractibility variable, the result also had no effect on SKPD performance.
\end{abstract}

Keywords: Incentive-oriented Performance Appraisal System, Performance-oriented Appraisal Performance System, Contractibility, SKPD Performance. 


\section{Pendahuluan}

Kinerja pelayanan publik menjadi isu kebijakan yang semakin strategis karena perbaikan kinerja pemerintah memiliki implikasi yang luas dalam kehidupan ekonomi dan politik. Dalam kehidupan ekonomi, perbaikan kinerja pemerintah akan dapat memperbaiki iklim investasi yang amat diperlukan oleh bangsa ini agar dapat keluar dari krisis ekonomi yang berkepanjangan. Menurut Dwiyanto (2006) kinerja birokrasi publik di Indonesia dari berbagai studi dan observasi tidak banyak mengalami perbaikan, bahkan menjadi semakin buruk.

Semakin meningkatnya tuntutan Pemerintah terhadap penyelenggaraan pemerintahan yang baik dan bersih (Good governance dan clean government) melalui Instruksi Presiden Nomor 7 tahun 1999 tentang Akuntabilitas Kinerja Instansi Pemerintah telah mendorong pengembangan dan penerapan sistem pertanggungjawaban yang jelas dan teratur dan efektif yang dikenal dengan Sistem Akuntabilitas Kinerja Instansi Pemerintah (SAKIP) penerapan tersebut bertujuan agar penyelenggaraan pemerintahan dan pembangunan berdayaguna, berhasil guna dan bertanggungjawab dan bebas dari praktik kolusi, korupsi dan nepotisme (KKN). Dalam hal ini, setiap organisasi diwajibkan mencatat dan melaporkan setiap penggunaan keuangan negara serta kesesuaiannya dengan ketentuan yang berlaku. Produk akhir SAKIP yang menggambarkan kinerja yang dicapai oleh suatu Instansi pemerintah atas pelaksanaan program dan kegiatan yang dibiayai APBN/APBD menghasilkan LAKIP yang merupakan Laporan Akuntabilitas Kinerja Instansi Pemerintah. Bagi seorang pimpinan atau kepala daerah, SAKIP akan berguna untuk bisa mengukur setiap pembangunan atau kinerja yang dilakukan masing-masing Satuan Kerja Perangkat Daerah (SKPD). Selain itu, sistem ini bisa juga dijadikan sebagai tolak ukur untuk mempertanggungjawabkan anggaran yang telah digunakan untuk pembangunan daerah.

Berdasarkan penelitian yang dilakukan oleh Spekle dan Verbeeten (2013) dijelaskan bahwa pengaruh sistem penilaian kinerja berorientasi insentif terhadap kinerja adalah negatif, namun pada saat variabel contractibility yang tinggi memoderasi diantaranya memberikan pengurangan terhadap nilai negatif awal. Kesimpulan yang dihasilkan menyatakan bahwa variabel contractibility dapat memoderasi pengaruh sistem penilaian kinerja berorientasi insentif terhadap kinerja. Dalam penelitian ini juga ditambahkan faktor penilaian kinerja berorientasi eksplorasi.

Oleh karena itu, penelitian ini diharapkan dapat memberikan jawaban mengapa penilaian SAKIP untuk kabupaten/kota di Indonesia tidak ada yang bernilai A, Hipotesis kami berada pada pengaruh variabel moderasi yaitu contractibility.

\section{Identifikasi Masalah}

Identifikasi masalah dari penelitian ini adalah:

1. Apakah sistem penilaian kinerja berorientasi insentif berpengaruh secara signifikan terhadap kinerja SKPD di Kota Bandung?

2. Apakah sistem penilaian kinerja berorientasi eksplorasi berpengaruh secara signifikan terhadap kinerja SKPD di Kota Bandung?

3. Apakah sistem penilaian kinerja berorientasi insentif berpengaruh secara signifikan terhadap kinerja SKPD di Kota Bandung yang dimoderasi oleh variabel contractibility?

4. Apakah sistem penilaian kinerja berorientasi eksplorasi berpengaruh secara signifikan terhadap kinerja SKPD di Kota Bandung yang dimoderasi oleh variabel contractibility? 


\section{Tujuan dan Manfaat Penelitian}

Yang menjadi tujuan dari penelitian ini adalah:

1. Untuk mengetahui pengaruh sistem penilaian kinerja berorientasi insentif terhadap kinerja SKPD di Kota Bandung.

2. Untuk mengetahui pengaruh sistem penilaian kinerja berorientasi eksplorasi terhadap kinerja SKPD di Kota Bandung.

3. Untuk mengetahui pengaruh sistem penilaian kinerja berorientasi insentif terhadap kinerja SKPD di Kota Bandung yang dimoderasi oleh variabel contractibility.

4. Untuk mengetahui pengaruh sistem penilaian kinerja berorientasi eksplorasi terhadap kinerja SKPD di Kota Bandung yang dimoderasi oleh variabel contractibility.

\section{Kerangka Teoritis dan Hipotesis}

\section{Konsep Kinerja Organisasi}

Kinerja adalah gambaran mengenai tingkat pencapaian pelaksanaan suatu kegiatan/program/kebijakan dalam mewujudkan sasaran, tujuan, misi, dan visi organisasi yang tertuang dalam strategic planning suatu organisasi (Mahsun, 2009).

\section{Indikator Kinerja Sektor Publik}

Peraturan Menteri Pendayagunaan Aparatur Negara dan Reformasi Birokrasi no. 38 Tahun 2012 tentang pedoman penilaian kinerja unit pelayanan publik memberikan indikator-indikator penilaian sebagai berikut:

1. Pada visi, misi dan motto pelayanan terdapat indikator penilaian yang meliputi:

a. Adanya visi dan misi yang dijabarkan dalam perencanaan (renstra, renja) mengacu UU No. 25 tahun 2009 ttg pelayanan publik b. Penetapan motto pelayanan yang mampu memotivasi pegawai untuk memberikan pelayanan terbaik.

c. Motto pelayanan diumumkan secara luas kepada pengguna layanan.

2. Standar pelayanan dan maklumat pelayanan. Sebagai upaya memberikan kepastian, meningkatkan kualitas, dan kinerja pelayanan sesuai dengan kebutuhan masyarakat dan selaras dengan kemampuan penyelenggaraan sehingga mendapatkan kepercayaan masyarakat, maka penyelenggaraan pelayanan perlu menyusun, menetapkan, dan menerapkan standar pelayanan. Indikator yang dinilai dalam standar pelayanan dan maklumat pelayanan adalah:

a. Penyusunan, penetapan, dan penerapan standar pelayanan mengacu pada UU No. 25 tahun 2009 tentang pelayanan publik

b. Maklumat pelayanan yang dipublikasikan.

3. Sistem, mekanisme, dan prosedur. Untuk memberikan kepuasan kepada masyarakat melalui pelayanan yang diberikan menggunakan sistem dan mekanisme pelayanan yang sesuai dengan kebutuhan. Hal ini dilakukan dengan prosedur dan standar operasional prosedur. Indikator yang dinilai dalam komponen ini adalah:

a. Memiliki sertifikat ISO 9001:2008 dalam menyelenggarakan pelayanan publik dengan ruang lingkup semua jenis yang mengacu pada UU No. 25 tahun 2009 tentang pelayanan publik.

b. Menerapkan Sistem Manajemen Mutu (SMM), namun tidak memiliki sertifikat ISO 9001:2008.

c. Penetapan Standar Operasional Prosedur (SOP).

d. Penetapan uraian tugas yang jelas.

4. Sumber Daya Manusia. Pada aspek SDM merupakan bentuk profesionalisme pegawai yang meliputi sikap dan perilaku, keterampilan, 
kepekaan, dan kedisiplinan. Indikator yang dinailai dalam komponen ini adalah:

a. Penetapan dan penerapan pedoman kode etik pegawai.

b. Sikap dan perilaku pegawai dalam memberikan pelayanan kepada para pengguna layanan.

c. Tingkat kedisiplinan pegawai dalam memberikan pelayanan kepada pengguna layanan.

d. Tingkat kepekaan/respon pegawai dalam memberikan pelayanan kepada pengguna layanan.

e. Tingkat keterampilan pegawai dalam memberikan pelayanan kepada pengguna layanan.

f. Penetapan kebijakan pengembangan pegawai dalam rangka peningkatan keterampilan/profesionalisme

pegawai dengan tujuan meningkatkan kualitas pelayanan kepada pengguna pelayanan.

5. Sarana dan prasarana pelayanan. Sarana dan prasarana sebagai media dan instrumen dalam memberikan pelayanan kepada masyarakat. Indikator penilaiannya meliputi:

a. Sarana dan prasarana yang dipergunakan untuk proses pelayanan telah didayagunakan secara optimal.

b. Sarana dan prasarana pelayanan yang tersedia memberikan kenyamanan kepada pengguna layanan. Dilihat dari kebersihan, kesederhanaan, kelayakan, dan kemanfaatan.

c. Sarana pengaduan, misalnya kotak pengaduaan, loket pengaduan, email dan lain sebagainya.

6. Penanganan pengaduan. Komponen ini berkaitan dengan aspek penanganan pengaduan dan penyelesaian terhadap pengaduan sesuai dengan ketentuan yang berlaku. Indikator penilaian komponen ini meliputi:

a. Sistem atau prosedur pengelolaan pengaduan pengguna layanan. b. Petugas khusus/unit yang menangani pengelolaan pengaduan.

c. Presentase jumlah pengaduan yang dapat diselesaikan

d. Pengelolaan pengaduan yang mengacu pada Peraturan Menteri PAN-RB No. 13 Tahun 2009 tentang Pedoman Peningkatan Kualitas Pelayanan dengan Partisipasi Masyarakat dalam rangka peningkatan kualitas pelayanan.

7. Indeks Kepuasan Masyarakat (IKM). Komponen IKM ini merujuk pada tingkat kepuasan masyarakat dalam menerima pelayanan. Indikator penilaiannya meliputi:

a. Pelaksanaan survei IKM dalam periode penilaian.

b. Survei IKM yang dilakukan mengacu Kepmen Nomor 25 Tahun 2004 dalam periode penilaian.

c. Rata-rata skor IKM yang diperoleh.

d. Tindak lanjut dari hasil survei.

8. Sistem informasi pelayanan publik. Komponen ini tentang pengelolaan sistem informasi publik dalam bentuk penyampaian informasi dan keterbukaan informasi layanan publik. Indikator penilaiannya meliputi:

a. Sistem informasi pelayanan secara elektronik.

b. Penyampaian informasi pelayanan publik kepada pengguna layanan.

c. Tingkat keterbukaan informasi pelayanan kepada pengguna layanan.

9. Produktivitas dalam pencapaian target pelayanan. Pada komponen ini berkaitan dengan penentuan target pelayanan yang ingin dicapai. Indikator penilaianya adalah:
a. Penetapan target kinerja pelayanan.

b. Tingkat pencapaian target kinerja.

\section{Prinsip Pengukuran Kinerja}

Prinsip Pengukuran Kinerja yakni sebagai berikut:

1. Seluruh aktivitas kerja yang signifikan harus diukur 
2. Pekerjaan yang tidak diukur atau dinilai tidak dapat dikelola karena darinya tidak ada informasi yang bersifat obyektif untuk menentukan nilainya

3. Kerja yang tak diukur selayaknya diminimalisir atau bahkan ditiadakan

4. Keluaran kinerja yang diharapkan harus ditetapkan untuk seluruh kerja yang diukur

5. Hasil keluaran menyediakan dasar untuk menetapkan akuntabilitas hasil alih-alih sekadar mengetahui tingkat usaha

6. Mendefinisikan kinerja dalam artian hasil kerja semacam apa yang diinginkan adalah cara manajer dan pengawas untuk membuat penugasan kerja dari mereka menjadi operasional

7. Pelaporan kinerja dan analisis variansi harus dilakukan secara kerap

8. Pelaporan yang kerap memungkinkan adanya tindakan korektif yang segera dan tepat waktu

9. Tindakan korektif yang tepat waktu begitu dibutuhkan untuk manajemen kendali yang efektif.

\section{Penggunaan Sistem Pengukuran Kinerja}

Dalam tinjauan ekstensif dari literatur kinerja, terdapat 16 sistem pengukuran kinerja yang berbeda di setiap organisasi. Kelompok peran sistem ini dibagi menjadi lima kategori besar yaitu (1) mengukur kinerja, termasuk kemajuan monitoring, mengukur dan mengevaluasi kinerja; (2) strategy management, yang meliputi perencanaan, strategi formulasi / pelaksanaan / eksekusi, perhatian fokus, dan keselarasan; (3) internal dan eksternal komunikasi, benchmarking, dan sesuai dengan peraturan; (4) mempengaruhi perilaku, yang terdiri perilaku bermanfaat, mengelola hubungan, dan kontrol; dan (5) pembelajaran dan peningkatan, menangkap umpan balik (feedback), dan peningkatan kinerja (Franco-Santos et al., 2007 dalam Speklé dan Verbeeten 2013).

\section{Pengukuran Kinerja Berorientasi Insentif}

Penilaian kinerja seseorang harus disertai reward (penghargaan) yang bisa memotivasi dan memicu peningkatan kinerja. Reward tidak harus diwujudkan dalam bentuk finansial seperti gaji atau bonus, tetapi reward dapat berbentuk pujian atau sanjungan sebagai ungkapan penghargaan dan pengakuan atas prestasi yang dicapai (Mahsun, 2009).

Reward pada umumnya diwujudkan dalam bentuk finansial/insentif moneter. Insentif moneter merupakan suatu ekstra di atas kompensasi dan gaji pokok. Praktik pemberian reward sebagai upaya peningkatan kinerja perlu mempertimbangkan faktor-faktor penting sebagai berikut (Mahsun, 2009):

1. Membuat pembayaran atas kinerja sebagai bagian integral dan rencana formal organisasi.

2. Penentuan insentif dasar berdasarkan data kinerja yang akurat dan obyektif.

3. Pegawai dilibatkan dalam pengembangan, implementasi, dan revisi formula pembayaran kinerja.

4. Rencana kerja secara konsisten.

5. Reward kelompok kerja dan individual berdasarkan kontribusi kerja.

6. Sistem pengawasan dan penilaian kinerja harus transparan.

7. Pemberian insentif moneter harus disertai penghargaan yang dapat meningkatkan kepuasan pegawai.

Orientasi insentif digunakan untuk memeriksa dampak dari New Public Management dengan menggunakan sistem pengukuran kinerja. Program New Public Management menekankan peran kinerja sistem pengukuran dalam pengaturan sasaran, pemberian insentif (Newberry dan Pallot, 2004 dalam Speklé dan Verbeeten 2013). Dua karakteristik umum dari pemikiran New Public Management adalah pengenalan rasionalitas ekonomi dan efisiensi sebagai prinsip-prinsip yang 
menyeluruh, dan keyakinan dalam efek menguntungkan dari praktek manajemen seperti bisnis dan instrumen termasuk praktek pengukuran kinerja (Bogt et al., 2010 dalam Speklé dan Verbeeten 2013).

\section{Pengukuran Kinerja Berorientasi Eksplorasi \\ Menurut Spekle dan Verbeeten dalam Primastiwi (2017) sistem dengan penggunaan untuk tujuan eksplorasi melibatkan eksperimen, pembelajaran, adaptasi terhadap pandangan-pandangan yang sedang berkembang, dan kesediaan untuk terlibat dalam suatu debat organisasi menyangkut skala prioritas dan pembangunan di masa mendatang.}

\section{Contractibility (Perjanjian kinerja)}

Peraturan Presiden No. 29 Tahun 2014 tentang Sistem Akuntabilitas Kinerja Instansi Pemerintah (SAKIP). Penyelenggara SAKIP pada SKPD dilaksanakan oleh Entitas Akuntabilitas Kinerja SKPD. SKPD menyusun rencana strategis sebagai dokumen perencanaan SKPD untuk periode lima tahun. Setiap entitas Akuntabilitas Kinerja menyusun Rencana Kerja dan Anggaran yang ditetapkan dalam dokumen pelaksanaan anggaran. Dokumen pelaksanaan anggaran menjadi dasar penyusunan perjanjian kinerja. Perjanjian kinerja adalah lembar/dokumen yang berisikan penugasan dari pimpinan instansi yang lebih tinggi kepada pimpinan instansi yang lebih rendah untuk melaksanakan program/kegiatan yang disertai dengan indikator kinerja.

\section{Hipotesis}

Perumusan hipotesis dalam penelitian ini terbagi dalam 4 bagian sebagai berikut:

$\mathrm{H}_{1}=$ Terdapat pengaruh antara sistem penilaian kinerja berorientasi insentif terhadap kinerja SKPD di Kota Bandung. $\mathrm{H}_{2}=$ Terdapat pengaruh antara sistem penilaian kinerja berorientasi eksplorasi terhadap kinerja SKPD di Kota Bandung.
$\mathrm{H}_{3}=$ Terdapat pengaruh antara sistem penilaian kinerja berorientasi insentif terhadap kinerja SKPD di Kota Bandung yang dimoderasi oleh variabel contractibility.

$\mathrm{H}_{4}=$ Terdapat pengaruh antara sistem penilaian kinerja berorientasi eksplorasi terhadap kinerja SKPD di Kota Bandung yang dimoderasi oleh variabel contractibility.

\section{Metode Penelitian}

\section{Desain Penelitian}

Penelitian ini merupakan penelitian deskriptif analisis. Penelitian ini mencoba menganalisis pengaruh sistem penilaian kinerja berorientasi insentif, sistem penilaian kinerja berorientasi eksplorasi dengan dimoderasi oleh variabel contractibility terhadap kinerja SKPD di kota Bandung.

\section{Subjek/Objek Penelitian}

Objek dalam penelitian ini terdiri dari empat variabel yaitu sistem penilaian kinerja berorientasi insentif, sistem penilaian kinerja berorientasi eksplorasi, contractibility, dan kinerja SKPD. Sehubungan dengan objek penelitian tersebut, maka tempat yang dijadikan sebagai subjek dalam penelitian ini adalah 3 SKPD di kota Bandung yaitu Dinas Komunikasi \& Informatika (Jl Wastukancana No.2); Badan Perencanaan Pembangunan Daerah (Jl Taman Sari No 76); dan Dinas Hukum \& HAM (Jl Wastukancana No.2).

\section{Populasi dan Sampel Penelitian}

Populasi adalah wilayah generalisasi yang terdiri atas objek atau subjek yang mempunyai kualitas dan karakteristik tertentu yang ditetapkan oleh peneliti untuk dipelajari dan kemudian ditarik kesimpulan (Sugiyono, 2011). Populasi pada penelitian ini mencakup seluruh PNS yang bekerja pada 3 SKPD yang menjadi subjek 
penelitian. Sampel adalah bagian dari jumlah dan karakteristik yang dimiliki oleh populasi tersebut (Sugiyono, 2011). Sampel dalam penelitian ini berjumlah 60 responden.Teknik pengambilan sampel yang digunakan adalah random sampling dimana setiap unit dalam populasi mempunyai kesempatan yang sama untuk dipilih menjadi anggota sampel.

\section{Teknik Pengumpulan Data}

Secara umum digunakan dua jenis data dalam penelitian ini, yakni data primer dan data sekunder. Data primer dikumpulkan melalui kuesioner. Data sekunder diperoleh dari studi pustaka dan telaah literatur yang terkait baik melalui buku teks, jurnal-jurnal ilmiah, serta publikasi lain yang terkait.

\section{Teknik Pengujian Data}

Data pada penelitian ini dilakukan uji validitas dan uji reliabilitas. Validitas berhubungan dengan ketepatan alat ukur untuk melakukan tugasnya mencapai sasarannya (Hartono, 2011). Reliabilitas berhubungan dengan akurasi dari pengukuran. Suatu pengukur dikatakan reliabel jika dapat dipercaya (Hartono, 2011). Kemudian untuk memenuhi persyaratan statistik juga dilakukan uji asumsi klasik yang meliputi uji normalitas, uji multikolinearitas, dan uji heterokedastisitas.

\section{Metode Analisis Data}

Untuk menganalisis data dalam penelitian ini digunakan Moderated Regression Analysis (MRA). Model persamaan untuk penelitian ini adalah sebagai berikut:

1. $Y=a+b . X 1$

2. $Y=a+b \cdot X 2$

3. $Y=a+b . M O D 1$

4. $\mathrm{Y}=\mathrm{a}+\mathrm{b} \cdot \mathrm{MOD} 2$

Keterangan:

Y: $\quad$ kinerja SKPD

a: koefisien intercept (konstanta) yaitu nilai $\mathrm{Y}$ jika nilai seluruh variabel lain adalah nol.

b: koefisien regresi
X1: sistem penilaian kinerja berorientasi insentif

$\mathrm{X} 2$ : $\quad$ sistem penilaian kinerja berorientasi eksplorasi

MOD1: sistem penilaian kinerja berorientasi insentif dimoderasi oleh variabel contractibility

MOD2: sistem penilaian kinerja berorientasi eksplorasi dimoderasi oleh variabel contractibility

\section{Hasil Penelitian dan Pembahasan}

\section{Uji Validitas}

Hasil yang diperoleh menunjukan bahwa nilai korelasi (r) untuk variabel X1, X2, X3 dan $\mathrm{Y}$ berada di atas 0,3 maka semua item valid.

Tabel 1

Hasil Uji Validitas

\begin{tabular}{|c|l|c|}
\hline No & \multicolumn{1}{|c|}{ Variabel } & Keterangan \\
\hline 1 & $\begin{array}{l}\text { Sistem Penilaian } \\
\text { Kinerja Berorientasi } \\
\text { Insentif (X1) }\end{array}$ & $\begin{array}{c}\text { semua item } \\
\text { valid }\end{array}$ \\
\hline 2 & $\begin{array}{l}\text { Sistem Penilaian } \\
\text { Kinerja Berorientasi } \\
\text { Eksplorasi (X2) }\end{array}$ & $\begin{array}{c}\text { semua item } \\
\text { valid }\end{array}$ \\
\hline 3 & Contractibility (X3) & $\begin{array}{c}\text { semua item } \\
\text { valid } \\
\text { semua item } \\
\text { valid }\end{array}$ \\
\hline 4 & Kinerja SKPD (Y) \\
\hline
\end{tabular}

\section{Uji Reliabilitas}

Hasil perhitungan nilai reliabilitas pada tabel memperlihatkan bahwa untuk variabel sistem penilaian kinerja berorientasi insentif (X1) diperoleh nilai reliabilitas sebesar 0,919 , untuk variabel sistem penilaian kinerja berorientasi eksplorasi (X2) diperoleh nilai reliabilitas sebesar 0,915, untuk variabel contractibility (X3) diperoleh nilai reliabilitas sebesar 0,929, untuk variabel kinerja SKPD (Y) diperoleh nilai reliabilitas sebesar 0,982 . Terlihat 
bahwa masing-masing variabel memiliki nilai koefisien reliabilitas $>0,60$ sehingga dapat disimpulkan bahwa semua item dari setiap variabel $\mathrm{X}$ dan $\mathrm{Y}$ adalah reliabel dan dapat diuji lebih lanjut.

Tabel 2

\section{Hasil Uji Reliabilitas Instrumen Penelitian}

\begin{tabular}{|l|c|c|}
\hline $\begin{array}{c}\text { Jumlah butir } \\
\text { pertanyaan }\end{array}$ & $\begin{array}{c}\text { Koefisien } \\
\text { reliabilitas }\end{array}$ & Keterangan \\
\hline $\begin{array}{l}\text { Sistem } \\
\text { penilaian } \\
\text { kinerja } \\
\text { berorientasi } \\
\text { insentif (X1) } \\
\rightarrow 7\end{array}$ & 0,919 & Reliabel \\
\hline $\begin{array}{l}\text { Sistem } \\
\text { penilaian } \\
\text { kinerja } \\
\text { berorientasi } \\
\text { eksplorasi } \\
(\mathrm{X} 2) \rightarrow 4\end{array}$ & 0,915 & Reliabel \\
\hline $\begin{array}{l}\text { Contractibility } \\
(\mathrm{X} 3) \rightarrow 6\end{array}$ & 0,929 & Reliabel \\
\hline $\begin{array}{l}\text { Kinerja SKPD } \\
(\mathrm{Y}) \rightarrow 32\end{array}$ & 0,982 & Reliabel \\
\hline
\end{tabular}

\section{Model Persamaan Regresi}

Pada penelitian ini terdapat empat persamaan regresi yang digunakan. Persamaan pertama digunakan untuk menganalisis pengaruh sistem penilaian kinerja berorientasi insentif terhadap kinerja SKPD. Persamaan kedua digunakan untuk menganalisis pengaruh sistem penilaian kinerja berorientasi eksplorasi terhadap kinerja SKPD. Persamaan ketiga digunakan untuk menganalisis pengaruh sistem penilaian kinerja berorientasi insentif terhadap kinerja SKPD ketika dimoderasi oleh variabel contractibility. Persamaan keempat digunakan untuk menganalisis pengaruh sistem penilaian kinerja berorientasi eksplorasi terhadap kinerja SKPD ketika dimoderasi oleh variabel 48 contractibility. Model persamaan dalam penelitian ini adalah sebagai berikut:
(1) $Y=a+b . X 1$
(2) $Y=a+b . X 2$
(3) $\mathrm{Y}=\mathrm{a}+\mathrm{b} \cdot \mathrm{MOD} 1$
(4) $\mathrm{Y}=\mathrm{a}+\mathrm{b} \cdot \mathrm{MOD} 2$

Persamaan di atas dihitung dengan menggunakan Moderated Regression Analysis (MRA) dengan hasil perhitungan koefisien regresi sebagai berikut:

Tabel 3

Koefisien Regresi dan Uji Signifikansi

\begin{tabular}{|c|c|c|c|c|c|}
\hline \multicolumn{6}{|c|}{ Coefficients $^{\mathrm{a}}$} \\
\hline \multirow[t]{2}{*}{ Model } & \multicolumn{2}{|c|}{$\begin{array}{c}\text { Unstanda } \\
\text { rdized } \\
\text { Coefficie } \\
\text { nts }\end{array}$} & $\begin{array}{l}\text { Standar } \\
\text { dized } \\
\text { Coeffici } \\
\text { ents }\end{array}$ & $\mathrm{T}$ & $\begin{array}{l}\text { Si } \\
\text { g. }\end{array}$ \\
\hline & $B$ & $\begin{array}{l}\text { Std. } \\
\text { Err } \\
\text { or }\end{array}$ & Beta & & \\
\hline (Cons & 3,1 & ,40 & & 7,7 & , 0 \\
\hline tant) & 67 & 8 & & 58 & 0 \\
\hline $\mathrm{X} 1$ & $\begin{array}{r}- \\
, 22 \\
8\end{array}$ & $\begin{array}{r}, 42 \\
0\end{array}$ &,- 217 & $\begin{array}{r}, 54 \\
3\end{array}$ & $\begin{array}{l}, 5 \\
8 \\
9\end{array}$ \\
\hline $1 \times 2$ & $\begin{array}{r}- \\
, 41 \\
3\end{array}$ & $\begin{array}{r}38 \\
9\end{array}$ &,- 400 & $\begin{array}{r}1,0 \\
62\end{array}$ & $\begin{array}{r}2 \\
9 \\
3\end{array}$ \\
\hline MOD & ,08 & ,12 & .565 & 68 & $\begin{array}{r}4 \\
9\end{array}$ \\
\hline 1 & 3 & 1 & כ0נ, & 7 & 5 \\
\hline $\begin{array}{l}\text { MOD } \\
2\end{array}$ & $\begin{array}{r}12 \\
5\end{array}$ & $\begin{array}{r}12 \\
1\end{array}$ & ,812 & $\begin{array}{r}1,0 \\
36\end{array}$ & $\begin{array}{r}3 \\
0 \\
5\end{array}$ \\
\hline
\end{tabular}

a. Dependent Variable: $Y$

Hasil perhitungan koefisien regresi berdasarkan data penelitian yang diperoleh dapat ditulis dalam persamaan regresi sebagai berikut:

Persamaan pertama: $\mathrm{Y}=3,167-0,228 . \mathrm{X} 1$ Persamaan pertama memiliki tingkat signifikan 0,589 lebih besar dari 0,05, maka dapat dijelaskan bahwa sistem penilaian 
kinerja berorientasi insentif tidak berpengaruh terhadap kinerja SKPD.

Persamaan kedua: $\mathrm{Y}=3,167-0,413 . \mathrm{X} 2$

Persamaan kedua memiliki tingkat signifikan 0,293 lebih besar dari 0,05, maka dapat dijelaskan bahwa sistem penilaian kinerja berorientasi eksplorasi tidak berpengaruh terhadap kinerja SKPD.

Persamaan ketiga: $\mathrm{Y}=3,167+$ 0,083.MOD1

Persamaan ketiga memiliki tingkat signifikan 0,495 lebih besar dari 0,05, maka dapat dijelaskan bahwa sistem penilaian kinerja berorientasi insentif tidak berpengaruh terhadap kinerja SKPD ketika dimoderasi oleh variabel contractibility.

Persamaan keempat: $\mathrm{Y}=3,167+$

0,125.MOD2

Persamaan keempat memiliki tingkat signifikan 0,305 lebih besar dari 0,05, maka dapat dijelaskan bahwa sistem penilaian kinerja berorientasi eksplorasi tidak berpengaruh terhadap kinerja SKPD ketika dimoderasi oleh variabel contractibility.

\section{Pengujian Asumsi Klasik}

\section{Uji Normalitas}

Hasil perhitungan uji normalitas menggunakan Kolmogorov-Smirnov Test ditunjukkan pada tabel berikut:

Tabel 4

\begin{tabular}{|l|r|}
\multicolumn{3}{|c}{ Hasil Uji Normalitas } \\
\begin{tabular}{|ll|r|}
\hline \multicolumn{1}{|c|}{ One-Sample Kolmogorov-Smirnov Test } \\
\hline N & $\begin{array}{c}\text { Unstandardi } \\
\text { zed } \\
\text { Residual }\end{array}$ \\
\hline Normal Parameters & a,b & 60 \\
& Sean & $0 \mathrm{E}-7$ \\
Most Extreme & Deviation &, 42220322 \\
Differences & Absolute &, 159 \\
Kolmogorov-Smirnov Z & Nositive &, 084 \\
Asymp. Sig. (2-tailed) & & -159 \\
\hline
\end{tabular}
\end{tabular}

a. Test distribution is Normal.

b. Calculated from data.
Hasil yang diperoleh berdasarkan nilai signifikansi uji Kolmogorov-Smirnov Test pada tabel di atas dapat dilihat bahwa nilai probabilitas (sig.) untuk model persamaan penelitian ini diperoleh sebesar 0,096. Nilai probabilitas uji normalitas untuk masingmasing model regresi lebih besar dari 5\% atau 0,05 menunjukkan bahwa hasil taksiran model regresi mengikuti distribusi normal.

\section{Uji Multikolinearitas}

Hasil nilai VIF menunjukkan untuk ketiga variabel bebas memiliki nilai VIF lebih kecil dari 10, dimana nilai VIF yang lebih kecil dari 10 mengisyaratkan tidak adanya multikolinearitas. Selain itu juga nilai tolerance lebih dari 0,1 mengisyaratkan tidak adanya multikolinearitas. Maka disimpulkan tidak terjadi multikolinearitas antar variabel bebas dalam model regresi.

Tabel 5

\section{Hasil Uji Multikolinearitas}

\begin{tabular}{|c|c|c|c|c|c|c|c|}
\hline \multicolumn{8}{|c|}{ Coefficients $^{a}$} \\
\hline \multirow[t]{2}{*}{ Model } & \multicolumn{2}{|c|}{$\begin{array}{l}\text { Unstandar } \\
\text { dized } \\
\text { Coefficient } \\
\text { s }\end{array}$} & $\begin{array}{l}\text { Standard } \\
\text { ized } \\
\text { Coefficie } \\
\text { nts }\end{array}$ & \multirow[t]{2}{*}{$\mathrm{t}$} & \multirow[t]{2}{*}{$\begin{array}{l}\text { Si } \\
\text { g. }\end{array}$} & \multicolumn{2}{|c|}{$\begin{array}{l}\text { Collinearity } \\
\text { Statistics }\end{array}$} \\
\hline & $B$ & $\begin{array}{l}\text { Std } \\
\text { E. } \\
\text { Err } \\
\text { or }\end{array}$ & Beta & & & $\begin{array}{c}\text { Tolera } \\
\text { nce }\end{array}$ & VIF \\
\hline $\begin{array}{l}\text { (Const } \\
\text { ant) }\end{array}$ & ,423 & $\begin{array}{r}, 30 \\
2\end{array}$ & & $\begin{array}{r}1,4 \\
01\end{array}$ & $\begin{array}{l}, 1 \\
67\end{array}$ & & \\
\hline $\mathrm{X} 1$ & ,161 & $\begin{array}{r}, 12 \\
1\end{array}$ & ,154 & $\begin{array}{r}1,3 \\
27\end{array}$ & $\begin{array}{r}1 \\
90\end{array}$ & ,365 & $\begin{array}{r}2,7 \\
38\end{array}$ \\
\hline$\times 2$ &, 009 & $\begin{array}{r}, 10 \\
6\end{array}$ & ,009 & $\begin{array}{r}08 \\
9\end{array}$ & $\begin{array}{r}, 9 \\
29\end{array}$ & ,464 & $\begin{array}{r}2,1 \\
54\end{array}$ \\
\hline $\mathrm{X} 3$ & ,721 & $\begin{array}{r}, 10 \\
1\end{array}$ & ,729 & $\begin{array}{r}7,1 \\
39\end{array}$ & $\begin{array}{l}, 0 \\
00\end{array}$ & ,469 & $\begin{array}{r}2,1 \\
34\end{array}$ \\
\hline
\end{tabular}

\section{Uji Heterokedastisitas}

Berdasarkan output Scatterplot di bawah ini dapat dilihat bahwa titik-titik data menyebar, tidak berkumpul di satu titik saja. Penyebaran titik-titik data tidak berpola sehingga dapat disimpulkan bahwa tidak terjadi masalah heterokedastisitas. 


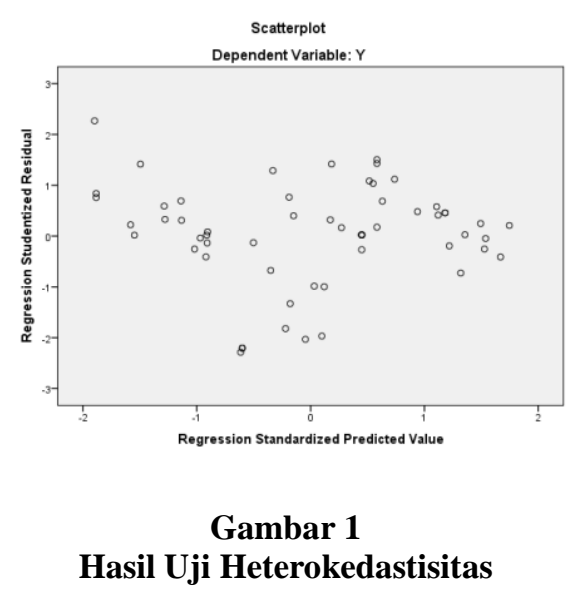

\section{Pembahasan}

\section{Pengaruh Sistem Penilaian Kinerja Berorientasi Insentif Terhadap Kinerja SKPD Di Kota Bandung}

Dari hasil data statistik yang diolah melalui uji signifikansi diperoleh nilai signifikan 0,589 lebih besar dari 0,05, maka dapat dijelaskan bahwa sistem penilaian kinerja berorientasi insentif tidak berpengaruh terhadap kinerja SKPD di kota Bandung.

\section{Pengaruh Sistem Penilaian Kinerja \\ Berorientasi Eksplorasi Terhadap \\ Kinerja SKPD di Kota Bandung}

Dari hasil data statistik yang diolah melalui uji signifikansi diperoleh nilai signifikan 0,293 lebih besar dari 0,05, maka dapat dijelaskan bahwa sistem penilaian kinerja berorientasi eksplorasi tidak berpengaruh terhadap kinerja SKPD di kota Bandung.

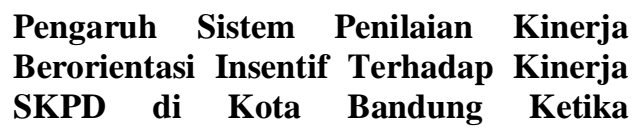
Dimoderasi Oleh Variabel Contractibility Dari hasil data statistik yang diolah melalui uji signifikansi diperoleh nilai signifikan 0,495 lebih besar dari 0,05, maka dapat dijelaskan bahwa sistem penilaian kinerja berorientasi insentif tidak berpengaruh terhadap kinerja SKPD di kota Bandung ketika dimoderasi oleh variabel contractibility.

Pengaruh Sistem Penilaian Kinerja Berorientasi Eksplorasi Terhadap Kinerja SKPD di Kota Bandung Ketika Dimoderasi Oleh Variabel Contractibility

Dari hasil data statistik yang diolah melalui uji signifikansi diperoleh nilai signifikan 0,305 lebih besar dari 0,05, maka dapat dijelaskan bahwa sistem penilaian kinerja berorientasi eksplorasi tidak berpengaruh terhadap kinerja SKPD di kota Bandung ketika dimoderasi oleh variabel contractibility.

Dalam penelitian ini sistem penilaian kinerja berorientasi insentif dan sistem penilaian kinerja berorientasi eksplorasi tidak berpengaruh terhadap kinerja SKPD, dan ketika dimoderasi oleh variabel contractibility hasilnya juga tidak ada pengaruh terhadap kinerja SKPD. Hal ini dapat terjadi karena banyak faktor yang mempengaruhi kinerja SKPD selain dari faktor sistem penilaian kinerja berorientasi insentif, sistem penilaian kinerja berorientasi eksplorasi, dan contractibility. Menurut Simanjuntak (2005) faktor-faktor yang dapat mempengaruhi kinerja antara lain adalah faktor kompetensi individu, faktor dukungan organisasi, dan dukungan manajemen. Faktor kompetensi individu terdiri dari kemampuan dan keterampilan kerja serta motivasi dan etos kerja. Faktor dukungan organisasi terdiri dari pengorganisasian, penyediaan sarana dan prasarana kerja, pemilihan teknologi, kenyamanan lingkungan kerja, serta kondisi dan syarat kerja. Faktor dukungan manajemen dilihat dari kemampuan manajerial para manajemen membangun sistem kerja yang baik dan mengembangkan kompetensi pekerja. 


\section{Simpulan dan Saran}

\section{Simpulan}

Dari hasil penelitian mengenai "Analisis Faktor-faktor yang Mempengaruhi Penilaian Kinerja SKPD di Kota Bandung" dapat disimpulkan bahwa:

1. Sistem penilaian kinerja berorientasi insentif tidak berpengaruh terhadap kinerja SKPD di kota Bandung.

2. Sistem penilaian kinerja berorientasi eksplorasi tidak berpengaruh terhadap kinerja SKPD di kota Bandung.

3. Sistem penilaian kinerja berorientasi insentif tidak berpengaruh terhadap kinerja SKPD di kota Bandung ketika dimoderasi oleh variabel contractibility.

4. Sistem penilaian kinerja berorientasi eksplorasi tidak berpengaruh terhadap kinerja SKPD di kota Bandung ketika dimoderasi oleh variabel contractibility.

\section{Saran}

Beberapa saran yang penulis ajukan berkaitan dengan hasil penelitian ini adalah:

1. Berkaitan dengan sistem penilaian kinerja berorientasi insentif maka disarankan kepada pimpinan organisasi/SKPD untuk meningkatkan penilaian data kinerja yang akurat dan obyektif sebagai dasar pemberian insentif kepada pegawai, membangun sistem pembayaran untuk rencana kerja secara lebih konsisten, dan meningkatkan pemberian insentif disertai dengan penghargaan (reward) yang dapat meningkatkan kepuasan pegawai.

2. Berkaitan dengan sistem penilaian kinerja berorientasi eksplorasi maka disarankan kepada pimpinan organisasi/SKPD untuk lebih membuka kesempatan bagi pegawai untuk berdiskusi dan memberikan masukan berupa ide dan meningkatkan melakukan pembelajaran dan adaptasi terhadap pandangan-pandangan yang baru berkembang.
3. Berkaitan dengan contractibility (perjanjian kinerja) maka disarankan kepada pimpinan organisasi/SKPD untuk selalu memperhatikan perjanjian kinerja karena di dalam perjanjian kinerja terdapat target kinerja organisasi yang berisikan penugasan untuk melaksanakan program/kegiatan.

4. Berkaitan dengan kinerja SKPD yang sudah cukup baik maka disarankan untuk lebih meningkatkan kinerjanya terutama dalam hal pelayanan terhadap masyarakat.

5. Untuk peneliti selanjutnya disarankan agar dalam penelitian selanjutnya dapat menggunakan responden yang berbeda, jumlah responden yang lebih banyak agar hasilnya menjadi lebih representatif.

\section{Daftar Pustaka}

Dwiyanto, Agus. (2006). Reformasi Birokrasi Publik di Indonesia. Yogyakarta: Gadjah Mada University Press.

Hartono.(2011). Metodologi Penelitian. Pekanbaru: Zanafa Publishing.

Instruksi Presiden Nomor 7 tahun 1999:

Akuntabilitas Kinerja Instansi

Pemerintah.

Mahsun, M. (2009). Pengukuran Kinerja Sektor Publik. Yogyakarta: BPFE

Peraturan Menteri Pendayagunaan Aparatur Negara dan Reformasi Birokrasi no. 38 Tahun 2012: Pedoman Penilaian Kinerja Unit Pelayanan Publik.

Peraturan Presiden No. 29 Tahun 2014: Sistem Akuntabilitas Kinerja Instansi Pemerintah (SAKIP).

Primastiwi, Anita. (2017) Pengaruh Informasi dan Sasaran yang Jelas dan Terukur terhadap Penggunaan Sistem Pengukuran Kinerja dan Dampaknya terhadap Kinerja Organisasi Sektor Publik. Efektif Jurnal Ekonomi dan Bisnis Universitas Janabadra, Vol 7, No. 1, hal. 22-44, e-ISSN: 2503-2968. 
Jurnal Akuntansi Maranathan Volume 10 Nomor 1, Mei 2018 : 41 - 52

Simanjuntak, Payaman J. (2005). Manajemen dan Evaluasi Kinerja. Jakarta: Fakultas Ekonomi Universitas Indonesia.

Spekle, Roland F. and Frank H.M. Verbeeten.(2013). The Use of Performance Measurement Systems in ThePublic Sector: Effects on

Performance.Management

Accounting Research, YMARE507, Pages 1-16.

Sugiyono.(2011). Metode Penelitian

Pendidikan. Bandung: Alfabeta. 